\title{
THE ENFORCEMENT OF CONDITIONS IN RIGHT OF ENTRY ORDERS ISSUED BY THE SURFACE RIGHTS BOARD
}

MAURICE J. SYCHUK, Q.C.*

\section{INTRODUCTION}

Section 15(6)(b) of the Surface Rights Act ${ }^{1}$ provides that the Surface Rights Board may make a right of entry order ${ }^{2}$ subject to any conditions it considers appropriate. The Board routinely makes its right of entry orders subject to conditions. The Board has prepared standard form conditions which it attaches to different types of right of entry orders ${ }^{3}$ and the Board will impose special conditions in specific cases. ${ }^{4}$

What rights and remedies does an owner ${ }^{5}$ or occupant ${ }^{6}$ have if the operator ${ }^{7}$ does not comply with a condition in a right of entry order?

This article discusses the jurisdiction of the Surface Rights Board and the procedure to be followed in obtaining compensation from the Board for a breach of a condition in a right of entry order, e.g., a review, pursuant to s. 32 of the Surface Rights Act, of the original compensation awarded by the Board on the basis that the original compensation had been calculated on the assumption that the operator would comply with the conditions in the right of entry order.

\section{BACKGROUND}

On September 9, 1981, Ranger Oil Limited applied to the Surface Rights Board for a right of entry order with respect to certain lands owned by the Crown and occupied by Légal Oil \& Gas Ltd. under a Mineral Surface Lease. ${ }^{8}$ Légal filed a Notice of Objection to the application for a right of entry order and the Board held a hearing on September 26, 1981.

The Board stated as follows in Decision No. E143/81 dated September 29, 1981:

After partial submission of the Applicant's evidence and after a requested and granted adjournment the parties advised the Board that they had reached agreement under the following terms and conditions.

The Applicant was granted immediate right of entry (to be interpreted as of the time the agreement was verbally made known to the board (approximately 5:30 p.m., September

* Professor of Law, University of Alberta. B.A., LL.B. (Sask.), M.C.L. (Southern Methodist University). Member of the Law Societies of Alberta, Saskatchewan and the Northwest Territories.

1. S.A. 1983 , c. S-27.1.

2. Defined in $s .1(n)$.

3. Various types of standard form conditions are set out in the Appendix hereto.

4. See for example Decision No. E103/80, E84/81 and E24/82.

5. Defined in $\mathrm{s.} 1(\mathrm{i})$.

6. Defined in s. $1(\mathrm{~g})$.

7. Defined in $\mathrm{s.}$ 1(h).

8. See Mineral Surface Lease Regulations, Alta. Reg. 228/58, as amended.

9. See Decision No. 16/71 (File No. R.E. 11878) dated January 13, 1971 and Order No. 1390/65 (File No. R.E. 10196) dated November 2, 1965 for examples of the basis for compensation when an applicant applies for a right of entry over lands occupied by another operator. 
26,1981 ) subject to a formal order being issued as soon as conveniently possible following resumption of normal hours of operation) with the following conditions to be attached to and form part of the order.

1. The Applicant will at all times maintain the said road in a good and proper condition and will perform such repair and maintenance work (except snow removal) as may be necessary to insure that the Respondent (Légal Oil \& Gas Ltd.) will be able to use the said road for its oil and gas operations.

2. The Applicant will not damage or cover the surface flow line on the west side of the road.

3. The Applicant is free to make such improvements to the said road as it wishes so long as the Applicant does not contravene any of the provisions of conditions 1 or 2 .

An order for compensation is requested consenting to the awarding of compensation to Légal Oil \& Gas Lid. as follows:

In the first year the said right of entry order is in effect the sum of TWELVE THOUSAND, FIVE HUNDRED and 00/100 DOLLARS $(\$ 12,500.00)$, to be paid, which sum shall cover all matters of compensation including costs of these proceedings before the Board; and

Annually thereafter, for each year or part thereof that the said order is in effect the sum of FIVE HUNDRED and 00/100 DOLLARS $(\$ 500.00) .{ }^{9}$

This decision as it relates to compensation is rendered on the understanding that the Applicant shall provide the Board with satisfactory evidence that there are no outstanding claims for compensation from any of the remaining respondents.

Therefore, orders will issue:

Granting right of entry effective September 26, 1981, with conditions as outlined hereinbefore; and

Awarding compensation payable to Légal Oil \& Gas Ltd. as hereinbefore set forth. ${ }^{10}$ that:

1. The Operator be and is granted right of entry as of September 26, 1981, in respect of the surface of the land shown outlined in red on Plans A and B attached hereto for the removal of minerals and for or incidental to any drilling operations;

2. The owner and any person claiming by, through or under him shall have the right to use the area shown outlined in red on the said plan

(a) for gaining access to the parts of his land severed or otherwise affected thereby, and

(b) for livestock at large,

and for those purposes the Operator shall provide such crossings and other works as may reasonably be required,

subject to the Operator's right to use the said area for its operations;

3. Where any land affected by this order has been previously acquired by the Respondent Légal Oil \& Gas Lid. for a well site and roadway the land so affected shall be held in common by the Operator and the said Respondent for the exercise of their respective rights;

4. Where any land affected by this order has been previously acquired by the Respondent Esso Resources Canada Limited for a pipeline the land so affected shall be held in common by the Operator and the said Respondent for the exercise of their respective rights; and

5. The right of entry is subject to the conditions attached hereto as Schedule B and forming part of this Order.

The above quoted three conditions were set forth in Schedule B to the said Order.

Légal subsequently alleged that Ranger was in breach of Condition No. 1. Ranger did not agree and Légal commenced proceedings to enforce Condition No. 1.

10. The said compensation was set forth in Order No. E1498/81 dated September 29, 1981 . 


\section{THE APPLICATION TO AMEND}

In an Application, dated September 10,1982, to the Surface Rights Board to Amend Compensation Order No. E1498/81, Légal stated:

TAKE NOTICE that Légal Oil \& Gas Ltd. does hereby apply, pursuant to Section 35(b) of The Surface Rights Act," for an Order of the Surface Rights Board amending Compensation Order No. E1498/81 to increase the amount of the first year compensation and to increase the amount of the annual compensation to be paid to Légal.

Pursuant to Section 18(1) of The Rules of Procedure and Practice of the Surface Rights Board, ${ }^{12}$ the reason for and the basis of the said application is the failure of Ranger Oil Limited to perform and comply with Condition No. 1 (Schedule B) of Right of Entry Order No. E1463/81, e.g., the Agreement between Légal and Ranger as to the amount of compensation to be awarded to Légal by the Surface Rights Board (See Decision No. E143/81) was negotiated and entered into by Légal on the basis that Ranger would comply with the said Condition No. 1 and Légal is therefore entitled to additional compensation for the damages suffered by Lègal as the result of Ranger's failure to do so.

Légal was not per se challenging the amount of the compensation determined in the original Order. The only reason that Légal was applying to amend the original compensation order was that that appeared to be the only way that the Surface Rights Board could deal with the issue of the breach of condition. An increase in the amount of the original compensation was not the end in itself, but was a means to the end, e.g., the real end in the said application was compensation for breach of the condition in the right of entry order, but an increase in the amount of the original compensation appeared to be the only means to the said end..$^{13}$

A similar approach to the issue of the costs of a local intervener on an appeal of a decision of the Energy Resources Conservation Board has been suggested by its solicitors, namely: ${ }^{14}$

One particular area of the Costs Regulation which has met with question is the provision for appeal. The only reference to an appeal is an appeal from the decision of a taxation officer. This is a procedure set out in ss. 8 and 9 of the Regulation but is totally foreign to the Board. The Board has never appointed a taxation officer and all costs decisions to date have emanated from the Board. In the two instances where the decision of the Board has been appealed, it was recommended to counsel for the local intervener to apply pursuant to s. 42 of the Energy Resources Conservation Act, which provides that:

"The Board may review, rescind, change, alter or vary any order or direction made by it, or may rehear any application before deciding it."

The Board held a hearing on the said Application to Amend in Swan Hills on June 6, 1983. In Decision No. E149/83, dated August 23, 1983, the Board stated:

The Operator argues in support of its opposition to a further award of compensation that the initial amount paid to the Respondent 15 was more than adequate to compensate for the problems now alleged, having regard to going rates in the area. It is also suggested that the Respondent is reaping a substantial benefit over what he is required to

11. R.S.A. 1980 , c. S-27, now s. 32(b).

12. Alta. Reg. $73 / 73$, now s. 10 of Alta. Reg. $239 / 83$.

13. As a result of this approach, Ranger took the position that the Application to Amend opened up the entire matter of the initial compensation (and not just the additional compensation caused by the breach) and submitted that the amount of the initial compensation should be reduced.

14. Bruni and Miller, "Practice and Procedure Before the Energy Resources Conservation Board" (1982) 20 Alta. Law Rev. 79, at 104.

15. Despite the fact that Légal made the Application to Amend, the Board refers to Légal as the Respondent because Légal was the Respondent in the original application for the right of entry. 
pay for the lease right granted to him by the Crown for the roadway in question. And it is further argued that the application by the Respondent opens the entire matter of compensation, and it lies to be found that the amount paid initially is highly excessive in the light of the facts.

In the Board's opinion, the Operator's argument is irrelevant, and if valid ought to have been a consideration by the Operator in the first instance. It cannot now be advanced to temper or abrogate a "party and party" agreement by which the Respondent was ostensibly persuaded to drop his objection to the right of entry. The agreement reached between the parties in connection with the right of entry is clear - the Respondent abandoned his objection to the right of entry and the Operator agreed to pay to the Respondent certain sums of money as compensation, contingent on the Operator's performance of certain conditions (as set out in Schedule B attached). It is the alleged noncompliance with those specific conditions of the agreement that led to the application herein.

On the photographic evidence and by personal inspection, ${ }^{16}$ the Board is persuaded that the coarse gravel used has caused and will cause problems for the Respondent in regards to maintenance in both winter and summer because of the rocks along the edge of the roadbed and in the ditches. It is the Board's opinion, on its viewing the situation, that a problem for the Respondent will likely continue for so long as the rocks remain where they are.

However, notwithstanding that finding that the operations of the Operator appear to have caused a damage to the interest of the Respondent, having heard the details of the Respondent's claim, the Board is satisfied that the claim has not been properly advanced in accordance with the provisions of the Act.

Section $35(b)$ reads: ${ }^{17}$

"The Board may review, rescind, amend or replace a decision or order made by the Board."

The request for review is brought by the Respondent on the grounds of non-compliance with the conditions under which the sum of compensation was agreed to between the parties. The particular condition which it is alleged has been violated reads as follows:

"The Applicant (Operator) will at all times maintain the said road in a good and proper condition and will perform such repair and maintenance work (except snow removal) as may be necessary to insure that the Respondent (Légal Oil \& Gas Lid.) will be able to use the said road for its oil and gas operations."

There is no evidence that the Operator did other than maintain the road in a condition which allowed its continued use by the Respondent, and in fact it is in evidence that it was necessary for the Operator to improve the roadbed to permit the passage of its drilling equipment. By the Respondent's own admission, the roadway was in need of gravelling and other improvement work at the time the Operator obtained the right of entry, and the condition for maintenance and repair cannot be interpreted as a means of having the roadway upgraded to a standard above that in which the Operator found it at entry.

In the circumstances, the Board finds no grounds for review of the sums of compensation agreed to between the parties. If a claim does lie for damages as a result of the gravelling done by the Operator, it is a claim of a nature which can only be brought pursuant to section $38^{18}$ of the Act. However, the quantum of the claim clearly exceeds the limitations imposed by that section.

The Respondent's application for review of the compensation payable by the Operator under Order No. E1498/81 is dismissed. There will be no costs.

16. Pursuant to s. 24 the Board may conduct an examination of any real or personal property in respect of which a compensation order may be made.

17. Now s. 32(b).

18. Now s. 33. 


\title{
IV. THE APPLICATION FOR CERTIORARI
}

By a letter to the Surface Rights Board dated September 13, 1983,19 counsel on behalf of Légal submitted that there was an error of law on the face of Board Decision No. E149/83 and requested a hearing pursuant to s. 32 to deal with the said error of law. The Board replied that it was not prepared to review Decision No. E149/83.

It was Légal's position that it did not have a right of appeal pursuant to s. 26 of the Surface Rights Act because Decision No. E149/83 did not provide for the payment of compensation as is required by the definition of compensation order in s. 1(b).

In Bergman v. Francana Oil and Gas Ltd., ${ }^{20}$ the Alberta Court of Appeal affirmed the decision of Madam Justice J.B. Veit ${ }^{21}$ that an order of the Surface Rights Board as to costs pursuant to Section 42 is not a compensation order within the meaning of Section 26. Madam Justice Veit stated at page 266 :

\begin{abstract}
I have concluded that $s .24(1)^{22}$ of the Act establishes a privative clause with a specific statutory exception relating to compensation orders. The statute itself does not consider costs to form part of the compensation order: they are not considered in s. $23 .{ }^{23}$ Section $33(4)^{24}$ of the Act goes so far as to state that in certain circumstances costs may be deducted from the compensation order, hence recognizing the difference between the two.

I am of the view, therefore, that while the possibility may exist for an appeal from a decision concerning costs by way of a prerogative writ, the board's decision on costs is not appealable pursuant to the provisions of $s .24,{ }^{23}$ because costs do not form part of the compensation order.
\end{abstract}

Further in this regard, ss. 22(3), 27(13), 28(9), 29(11), 30(9) and 33(4) provide that orders thereunder may be appealed as though they were a compensation order; $s .32$ does not contain a similar provision.

If Légal had been successful in its Application, it would have been able to argue that it had the right to appeal pursuant to the extended definition of "compensation order" in s. 26(2) because Order No. E1498/81 would have been amended or replaced. Subsections (c) and (d) of s. 26(4) make it clear that there is a difference between the reasons given by the Board for its decision ${ }^{26}$ and the compensation order.

19. See the headnote in Re Canadian Logistic Systems and Labour Relations Board (1984) 6 D.L.R. (4th) 106 (B.C.S.C.), namely:

An application for a judicial review of a decision of the British Columbia Labour Relations Board which does not allege absence or lack of jurisdiction may not be brought without first exhausting the internal avenue of appeal available under s. 36 of the Labour Code, R.S.B.C. 1979, c. 12, which provides that the board may, on application by any person or on its own motion, reconsider any decision made by it or a panel of the board.

20. [1985] 3 W.W.R. 664 .

21. (1983) 25 Alta. L.R. (2d) 264.

22. Now s. 26(1).

23. Now s. 25.

24. Now s. 42(5).

25. Now s. 26.

26. The Board is required to give reasons for its decision pursuant to $\mathrm{s} .7$ of the Administrative Procedures Act, R.S.A. 1980, c. A-2. By Alta. Reg. 135/80 the Surface Rights Board was designated as an authority to which the Administrative Procedures Act applies. 
For the above reasons, Légal made an application for certiorari with respect to Decision No. E149/83.27

In Decision No. E149/83, the Surface Rights Board stated that Légal should have brought its claim pursuant to s. 33 of the Surface Rights Act.

Despite the fact that there is no specific provision in the Surface Rights $\mathrm{Act}^{28}$ dealing with non-compliance with a condition in a right of entry order, it is obvious that had the problems herein arisen before the Board issued its original compensation order, ${ }^{29}$ the Board could have awarded compensation for Légal's claims pursuant to $s .25,30$ and as such, it was Légal's position that it should not be restricted to the limited provisions of s. 33, e.g., there is no limit on the amount of compensation that the Board can award pursuant to s. $25 . .^{31}$

If the Surface Rights Board did not have jurisdiction to enforce conditions inserted by it into a right of entry order, the said conditions would be meaningless and ineffective and could be breached by the operator at will, ${ }^{32}$ e.g., s. 33 is inadequate both as to the basis of the claim and the amount thereof. It was therefore Légal's position that it was reasonable and in the public interest to conclude that it was the intention of the Legislature that the Surface Rights Board have jurisdiction to resolve issues with respect to breaches of conditions pursuant to s. 32. ${ }^{33}$

Légal's application for certiorari was heard by the Honourable $\mathrm{Mr}$. Justice D.H. Bowen. Mr. Justice Bowen accepted Légal's submission that the provisions of $s .32$ applied to the enforcement of a condition prescribed by the Surface Rights Board in a right of entry order and enabled the Board to award compensation for a breach of the said condi-

27. Action No. 8403-05259, Judicial District of Edmonton.

28. Pursuant to s. 36(2) a right of entry order may be enforced in the same manner as a writ of possession issued on the order of the Court of Queen's Bench, but s. 36 does not appy to other provisions of the right of entry order.

29. See page 14 of Decision No. E61/84 wherein the Board awarded compensation for a breach, which occurred before the compensation hearing, of a condition with respect to fences.

30. Where a condition relates to the initial use of the land by the operator so that a breach could occur quite quickly, it is essential that the owner or occupant consider whether the Board should be requested to delay issuing a consent compensation order that has been agreed to by the parties until it has been determined whether the operator has in fact complied with the said condition.

31. At page 18 of Decision No. C101/80, the Board stated that the issue of injurious affection to the remainder of the land could be reviewed pursuant to s. 35 (now s. 32) at a later date.

32. This discussion does not consider whether Légal had the right to commence an action in Court for specific performance or damages because such proceedings would be contrary to the intention of the Legislature in setting up the Surface Rights Board in the first place.

33. Reid and David, Administrative Law and Practice (2nd ed. 1978), state at page 107:

The power to reconsider decisions is peculiar to tribunals. It is not found in the lawcourts. Its existence is the consequence of a general lack of provisions for appeal, particularly on questions of fact, from tribunals, and of the regulatory nature of most tribunals. In both respects the tribunals differ from the courts. The power to reconsider thus appears to be an appropriate means both for the correction of errors in the absence of an appeal and to permit adjustments to be made as changes in the regulated activity occur.

See also C.U.P.E., Local 41 v. Board of Industrial Relations 79 C.L.L.C. 103 (Alta. C.A.) and United Brotherhood of Carpenters and Joiners of America, Local 1460v. Board of Industrial Relations [1971] 2 W.W.R. 105 (Alta. C.A.). 
tion, and as such, it was not necessary for Mr. Justice Bowen to deal with the provisions of s. 33 of the Surface Rights Act. ${ }^{34}$

Légal's application for certiorari was granted by Mr. Justice Bowen on June 22, 1984. Counsel for Légal prepared a draft Order in the following terms:

1. That the interpretation of the condition with respect to repair and maintenance and its application to the facts is a question of law and the Surface Rights Board, once it had made a finding of fact that the coarse gravel and rocks had caused and would continue to cause problems in regard to the maintenance of the road, made an error of law when it concluded that the said condition was not breached because the road may have been improved.

2. That the application for an Order in the Nature of Certiorari is allowed and that Decision No. E149/83 of the Surface Rights Board dated August 23, 1983 is hereby quashed.

Counsel for Ranger did not agree with the wording of the said draft and Mr. Justice Bowen was requested to fix the terms of the said Order.

Mr. Justice Bowen confirmed that the above quoted paragraph 1 correctly expressed (although it did not use his exact words) his comments at the conclusion of the hearing, but he did not accept Légal's submission that it was entitled to have the error of law specified in the Order ${ }^{35} \mathrm{Mr}$. Justice Bowen did, however, agree that Légal was entitled to have the fact that he had found an error of law stated in the Order, and as a result, Paragraph 1 of the said Order read as follows:

That the Surface Rights Board made an error of law and an Order in the Nature of Certiorari be granted and that the whole of Decision No. E149/83 of the Surface Rights Board dated August 23, 1983 be quashed.

By a letter dated July 11,1984, Counsel for Légal wrote to the Surface Rights Board and submitted that, Decision No. E149/83 having been quashed, the Board was now in the same position that it had been in at the conclusion of the hearing on June 6, 1983, e.g., the Surface Rights Board must issue a decision with respect to the application made by Légal to amend compensation Order No. E1498/81 and the Board must do so on the basis of the evidence and the arguments submitted at the said hearing and in accordance with Mr. Justice Bowen's decision with respect to the error of law made by the Board in Decision No. E149/83.

The Board solicitor replied by a letter dated October 11, 1984 and stated that Decision No. E149/83 had disposed of Légal's Application to Amend Compensation Order No. E1498/81 and the said decision having been quashed, the Board was of the opinion that there was no proceeding before it which would allow a further decision and it was therefore necessary for Légal to make a new application.

By a letter dated April 4, 1985, Counsel for Légal wrote to the Surface Rights Board and advised that, on the authority of the decision in $R e$ Nicholson and Haldimand - Norfolk Regional Board of Commissioners of Police, ${ }^{36}$ an order in the nature of certiorari merely quashed the deci-

34. This conclusion is supported by $s .27(4)$ which confirms that $s .32$ is the paramount provision.

35. See the excerpt from the Judgment Roll in Great Plainsv. Lyka [1973] 5 W.W.R. 768 (Alta C.A.) wherein the error of law was specified.

36. (1981) 117 D.L.R. (3d) 604 , at pages $608-609$, Ontario Divisional Court, affirmed by the Ontario Court of Appeal, leave to appeal to the Supreme Court of Canada refused, (1981) 117 D.L.R. (3d) 750. 
sion of the Board and did not quash the entire proceeding of the Board and that it was not therefore necessary for Légal to make a new application to the Board.

By a letter dated May 6, 1985, the Chairman of the Surface Rights Board advised that the Board had concluded that the Court had only quashed the decision, and as such, a decision would issue in due course to conclude the proceedings.

\section{THE SECOND BOARD DECISION}

In Decision No. E213/85 dated August 7, 1985, the Surface Rights Board repeated most of Decision No. E149/83 and stated:

The compensation agreed to and awarded by the Board was $\$ 12,500.00$ for the first year and $\$ 500.00$ annually thereafter, payable by the Operator to the Respondent. Although in the Board's view the compensation agreed to is in consideration of some damage being done by the Operator's operations, and the Board has found that the maintenance clause to maintain the road in a useable condition has not been breached, there is the clear fact that rocks have been scattered along both sides of the road and could interfere with future maintenance, particularly brush control. This is a result of the Operator's use which could not reasonably have been contemplated in the original agreement on compensation or the provision of the maintenance clause in the order for right of entry.

The Board fixed the additional compensation payable to Légal at $\$ 3,785.00$ (Légal had requested $\$ 8,582.00$ ) and directed that Order No. E1498/81 be amended accordingly.

The final event took place on December 23, 1985 when the Board issued Decision No. E319/85 awarding Légal costs (pursuant to s. 42) in the sum of $\$ 4,012.00$.

\section{SUMMARY}

Decision No. E213/85 is an important precedent in the law of surface rights in Alberta because it establishes that the Surface Rights Board has, pursuant to s. 32, jurisdiction to award compensation for a breach of a condition in a right of entry order on the basis that the original compensation had been calculated on the assumption that the operator would comply with the conditions in the right of entry order, ${ }^{37}$ e.g., the owner or occupant is not restricted to s. 33 .

The said Decision should therefore answer the following concern expressed at page 3 of the 1984 Annual Report of the Farmers' Advocate of Alberta, namely:

One matter that is worthy of note and causes our Office concern is the fact that the Sur-

face Rights Board has expressed that they cannot enforce the conditions they attach to a Right-of-Entry Order.

37. See Decision No. E262/85 dated October 16, 1985 wherein the owner sought additional compensation pursuant to Section 32 because the operator had placed new installations on the well site. 


\section{APPENDIX}

Conditions for well site and roadway or well site only

\section{SCHEDULE A}

\section{of conditions attached to and forming part of Order No.}

1. The Operator shall conserve the top soil in a good and workmanlike manner, having regard to good soil conservation practices and any reasonable request or direction of the owner in connection therewith.

2. The Operator shall exercise reasonable precaution and take whatever measures are necessary to contain its operations to the area granted by the Order, including the travel and movement of vehicles and other equipment.

3. The Operator shall not knowingly obstruct or impede the natural drainage of the remainder of the land, and to that end shall install or construct such culverts and other works as the owner may reasonably require.

4. The Operator shall construct and maintain such fences and other works and to such standard as the owner or any person claiming by, through or under him may reasonably require to ensure the safety and prevent the straying of livestock.

5. Except as may be authorized by any other Act, the Operator shall not drill any well on the area granted for the purpose of obtaining water for domestic use, except by prior consent of the owner.

6. The Operator shall prevent noxious weeds from growing on the area granted, in compliance with the Weed Control Act as to the prevention and destruction of same.

7. The Operator, and its agents, contractors and employees, and any other person or persons, shall not engage in the wanton discharge of firearms on or adjoining the area granted by the Order, nor shall any domestic animals in the keeping of such agents, contractors, employees or other persons be allowed to roam at large in the area.

Conditions for pipeline or for meter station site and pipeline

\section{SCHEDULE A}

\section{of conditions attached to and forming part of Order No.}

1. The Operator shall conserve the top soil in a good and workmanlike manner, having regard to good soil conservation practices and any reasonable request or direction of the owner in connection therewith. 
2. The Operator shall exercise reasonable precaution and take whatever measures are necessary to contain its operations to the area granted by the Order, including the travel and movement of vehicles and other equipment.

3. The Operator shall, during the construction of the pipeline and subsequent reclamation work, take all reasonable precautions to ensure that the natural drainage of the land is not obstructed or impeded.

4. If any above-ground installation is required in connection with the pipeline on the right of way, such installation shall, subject to any superseding requirement of sound engineering principles, be so located as to cause the minimum inconvenience to farming operations and shall be adequately marked and protected by a pipe or other metal structure clearly visible to the farm operator.

5. Should a leak or break occur in the pipeline on the right of way, the Operator shall immediately cause the owner or occupant of the land to be notified and informed of the location of the leak or break, and advise the owner of the measures being taken to contain, repair and clean up the leak or break.

6. The Operator shall be responsible for any damage done to crops or personal property of the owner or occupant of the land caused by any entry or re-entry thereon by the Operator, or any person acting by, through or under him, for any purpose authorized pursuant to the Pipeline Act.

Conditions for power transmission line

SCHEDULE A

of conditions attached to and forming part

of Order No.

1. The Operator shall make a reasonable attempt, prior to commencing actual construction (excluding surveying) of the transmission line, to consult with or advise the landowner as to the approximate location of any proposed structures on the right of way, and where the Operator can exercise a discretion on the precise placement of such structures shall locate them so as to cause the minimum of inconvenience to the agricultural use of the land.

2. The Operator shall exercise all reasonable precaution to contain its operations to the right of way including, but without limiting the generality of the foregoing, the removal of tree growth and the travel and movement of vehicles and equipment.

3. The Operator shall not use any soil sterilant for control or eradication of weeds or other vegetative growth in its operations on the right of way, unless requested by the landowner. 
4. The Operator shall properly repair any fences damaged as a result of its operations, or install adequate and secure gates if required by the Operator for future access to the right of way.

5. Upon completion of construction, or as soon as possible thereafter, the Operator shall clean the right of way of all loose debris of any nature resulting from its operations.

6. The Operator shall repair any damage done on the right of way by the travel of vehicles and equipment during any of its operations thereon, or shall cause the owner or occupant to be compensated for doing such repair work.

7. To the extent that the Surface Rights Act applies, the Operator shall be responsible for, and shall cause the owner or occupant to be compensated for, any damage to crops or personal property of the owner or occupant resulting from any entry or re-entry on the right of way by the Operator, or any person claiming by, through or under it, for any authorized purpose.

Conditions for battery site

SCHEDULE A

of conditions attached to and forming part

of Order No.

1. The Operator shall exercise all reasonable precaution to contain its operations to the right of way including, but without limiting the generality of the foregoing, the removal of tree growth and the travel and movement of vehicles and equipment.

2. The Operator shall construct and maintain such fences and other works and to such standard as the owner or any person claiming by, through or under him may reasonably require to ensure the safety and prevent the straying of livestock.

3. The Operator shall prevent noxious weeds from growing on the area granted, in compliance with the Weed Control Act as to the prevention and destruction of same. 